\title{
BLOOD DONOR BEHAVIOUR AND BLOOD GROUP DISTRIBUTION IN CAMPS AND INSIDE INSTITUTIONS IN A PERIPHERAL/ MUNICIPAL AREA IN AP
}

\author{
Kodandarao Kuna ${ }^{1}$, Rameshbabu $B^{2}$
}

${ }^{1}$ Assistant Professor, Department of General Surgery, GIMSR, Visakhapatnam, Andhra Pradesh, India.

${ }^{2}$ Assistant Professor, Department of Pulmonary Surgery, GIMSR, Visakhapatnam, Andhra Pradesh, India.

\section{BACKGROUND}

ABSTRACT

Blood donation has become a routine procedure all over India, meeting the needs of the entire population of 1.3 billion of India. It is indeed appreciable as the complications relating to blood donation and transfusion are least, thereby not losing public confidence despite the fact that it is a very enormous exercise.

The aim is to study in detail the donor behaviour (Willingness and Turn-up) and the number of blood group donation in frequency of descending order in comparison with the average Indian frequency.

\section{MATERIALS AND METHODS}

About 1027 blood samples data for a period of recent one year from Apr 17 - Mar 18 is collected on request from a Peripheral Blood Bank (PBB) in a remote municipality in Andhra Pradesh. The data is analysed, and relevant conclusions drawn in comparison to the average Indian frequency of blood group distribution.

Study Design- It is a retrospective study of blood group data from a peripheral blood bank for the period from Apr 2017 - Mar 2018 (One year) of sample size of 1027.

\section{RESULTS}

Mass donations even at the institutional blood bank level is always better than those in camps. With improving transport facilities and the use of social media in-house blood donation can be encouraged as priority, and blood bank space and infrastructure may be widened to accommodate the mass of people attending for donating blood.

\section{CONCLUSION}

The donor turn-up for the issue of blood is more frequent in in-house blood banks than in outside camps and not related to seasons, but related to student exams, holidays and the birthday occasions of local politicians. For replacement in the issue of blood, the relatives and the near and dear ones of the patients need not be overstressed. Yet the student community and other local youths have to be motivated constantly and new local social groups including women have to be drawn into the fold of blood donation category. The blood group distribution in order of descending frequency remains the same in Indian average and PBB with marginal difference.

\section{KEY WORDS}

ABO, Blood Groups, Donors, Behaviour, Distribution.

HOW TO CITE THIS ARTICLE: Kuna K, Rameshbabu B. Blood donor behaviour and blood group distribution in camps and inside institutions in a peripheral/ municipal area in AP. J. Evolution Med. Dent. Sci. 2018;7(45):4870-4877, DOI: $10.14260 /$ jemds/2018/1085

\section{BACKGROUND}

Karl Landsteiner, Austrian physician discovered blood groups in 1900 and won Nobel Prize in 1930. Reuben Ottenberg performed the first blood transfusion using typing and crossmatching.

From 1987 to 2002 the sensitive high-risk serological screening tests(1) like HIV, HbsAg and HCV were developed. Later blood subgroups like A1 and A2 were evolved.

'Financial or Other Competing Interest': None.

Submission 27-09-2018, Peer Review 20-10-2018,

Acceptance 27-10-2018, Published 05-11-2018.

Corresponding Author:

Rameshbabu B,

Assistant Professor,

Department of Pulmonary Surgery,

GIMSR,

Visakhapatnam,

Andhra Pradesh, India.

E-mail: saradaramesh1960@gmail.com

DOI: $10.14260 /$ jemds/2018/1085
A1 constitutes about $80 \%$ and A2 $20 \%$ of total subgroups ' $\mathrm{e}$ ' antigen allele is found in $98 \%$ of the population. A rare Bombay blood group was discovered in the year 1952 by Dr. Bhende, Bhatia and Deshpande. It is almost considered as ' 0 ' group, as it shows no reactions to anti-A and anti-B. As per ISBT(2) (International Society of Blood Transfusion, 2008, the following code numbers are given).

\begin{tabular}{|c|c|}
\hline ISBT, 2008 Category & Code No. \\
\hline IND & 023 \\
\hline ABO & 001 \\
\hline $\mathrm{Rh}$ & 004 \\
\hline \multicolumn{2}{|c|}{ Table 1 } \\
\hline
\end{tabular}

\begin{tabular}{|c|c|}
\hline Blood Group & Indian Frequency \\
\hline $\mathrm{A}$ & $27 \%$ \\
\hline $\mathrm{B}$ & $31 \%$ \\
\hline $\mathrm{AB}$ & $8 \%$ \\
\hline $\mathrm{O}$ & $34 \%$ \\
\hline
\end{tabular}

Table 2. Frequency of Blood Group distribution in Indian Population(3), (4) 
More than $60 \%$ of Indian population constitute 0 and B blood groups. More than $90 \%$ of Indian population constitute $0, \mathrm{~B}$ and $\mathrm{A}$ blood groups.

Those donors between the age group of 18 - 60 years with adequate weight and $\mathrm{Hb}$ above 12.5 gms (Indian average) without co-morbid ailments like High BP, Diabetes, Renal failure and COPD and without high-risk infections like HbsAg, HIV, HCV, Syphilis and Malaria are selected for donation on their voluntary willingness. Usually no formal consent is taken from the donors, as they are not considered as patients. But the blood is not screened before donation for infections like HbsAg, HIV, HCV, Syphilis and Malaria nor it is tested for the type of blood group in mass donations. A rare blood group like the Bombay Blood Group is kept in mind while testing for cross-matching, though the group is nearer to ' $\mathrm{O}$ ' group in its biological behaviour.

\section{Aims and Objectives}

To study the blood donor behaviour(5) and also to study the blood group distribution pattern among the population comparing it with the Indian average distribution of blood groups. The difference in blood donations of certain groups of people at a particular period/ season in an year is also studied.

\section{MATERIALS AND METHODS}

Material for the study is the sourced data from a peripheral blood bank and the data is analysed at the research centre of GIMSR (Gitam Institute of Medical Sciences and Research), Rushikonda, Visakhapatnam, AP. Relevant statistical methods when applicable are followed wherever necessary. The blood group distribution pattern as per the sourced data is compared with the existing Indian pattern.

All the 1027 blood groups(6),(7),(8) were screened for HIV, HBsAg, HCV and also for Malaria and VDRL. Seven blood bags were reported for HBsAg, four for HIV and none for HCV. These days, syphilis has become rare in incidence with the most frequent use of penicillin in the past as the organism is very sensitive to it. But screening for malaria is a routine method with the QBC test, which is available everywhere. QBC test must be performed in every patient hailing from a tribal area for the issue of blood on replacement basis for the need of his patient. But often blood bag is issued to tribal patients free without asking for replacement, as they are treated on a priority basis. Malaria is both epidemic in rainy season and endemic throughout the year. Hence, it is better not to conduct camps in hill areas, particularly during that season. If at all blood has to be drawn from a patient from a hill area, it has to be thoroughly screened for all forms of malaria like the vivax, falciparum, ovale and malariae. Specialised laboratories must be established in health centres on hilltops to minimise the risk of cerebral malaria and ARDS.

\section{RESULTS}

The present changing trend in blood donation is shift from camps to institutions, as evidenced by the statistics from Table No. 3. This is because the facilities and the doctors available at the institutional level and also the fact that donors can attend to the Institutional Blood Bank at any given time to donate blood, facilitating their occupation and time. These days not much of motivation is necessary to draw donors. Hence, we are able to meet almost all the requirements of blood to the needy patients all over India, even with huge population. Mass donations even at the Institutional Blood Bank level is always better than those in camps. With improving transport facilities and the use of social media, in-house blood donation can be encouraged as a priority and blood bank space and infrastructure may be widened to accommodate the mass of people attending for donating blood.

\begin{tabular}{|c|c|c|c|c|c|c|c|c|c|c|c|}
\hline $\begin{array}{l}\text { 군 } \\
\frac{1}{2}\end{array}$ & 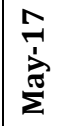 & 골 & $\stackrel{ }{\stackrel{1}{5}}$ & 告 & 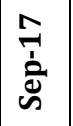 & בَّ & 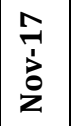 & 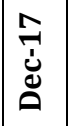 & $\stackrel{\infty}{\stackrel{\infty}{\Xi}}$ & $\begin{array}{l}\infty \\
\underset{1}{\dagger} \\
\stackrel{0}{0}\end{array}$ & 京 \\
\hline A & A & A & A & A & A & A & A & A & A & A & A \\
\hline$+\mathrm{VE}$ & $+\mathrm{VE}$ & $+\mathrm{VE}$ & $+\mathrm{VE}$ & $+\mathrm{VE}$ & $+\mathrm{VE}$ & $+\mathrm{VE}$ & $+\mathrm{VE}$ & $+\mathrm{VE}$ & $+\mathrm{VE}$ & $+\mathrm{VE}$ & $+\mathrm{VE}$ \\
\hline-13 & -33 & -16 & -31 & -12 & -14 & -22 & -08 & -12 & -03 & -05 & -02 \\
\hline B & B & B & $B$ & B & B & B & $B$ & B & B & B & B \\
\hline$+\mathrm{VE}$ & $+\mathrm{VE}$ & $+\mathrm{VE}$ & $+\mathrm{VE}$ & $+\mathrm{VE}$ & $+\mathrm{VE}$ & $+\mathrm{VE}$ & $+\mathrm{VE}$ & $+\mathrm{VE}$ & $+\mathrm{VE}$ & $+\mathrm{VE}$ & $+V E$ \\
\hline-25 & -47 & -31 & -28 & -24 & -19 & -35 & -25 & -16 & -13 & -14 & -05 \\
\hline 0 & 0 & 0 & 0 & 0 & 0 & 0 & 0 & 0 & 0 & 0 & 0 \\
\hline$+\mathrm{VE}$ & $+\mathrm{VE}$ & $+\mathrm{VE}$ & $+\mathrm{VE}$ & $+\mathrm{VE}$ & $+\mathrm{VE}$ & $+\mathrm{VE}$ & $+\mathrm{VE}$ & $+\mathrm{VE}$ & $+\mathrm{VE}$ & $+\mathrm{VE}$ & $+\mathrm{VE}$ \\
\hline-38 & -56 & -48 & -52 & -39 & -42 & -54 & -36 & -16 & -22 & -22 & -07 \\
\hline $\mathrm{AB}$ & $\mathrm{AB}$ & $\mathrm{AB}$ & $\mathrm{AB}$ & $\mathrm{AB}$ & $\mathrm{AB}$ & $A B$ & $\mathrm{AB}$ & $\mathrm{AB}$ & $\mathrm{AB}$ & $\mathrm{AB}$ & $\mathrm{AB}$ \\
\hline$+\mathrm{VE}$ & $+\mathrm{VE}$ & $+\mathrm{VE}$ & $+V E$ & $+V E$ & $+\mathrm{VE}$ & $+\mathrm{VE}$ & $+\mathrm{VE}$ & $+\mathrm{VE}$ & $+\mathrm{VE}$ & $+\mathrm{VE}$ & $+\mathrm{VE}$ \\
\hline-06 & -07 & -06 & -04 & -05 & -01 & -07 & -04 & -0 & -05 & -01 & -0 \\
\hline $\begin{array}{l}\text { A - } \\
V E-\end{array}$ & $\begin{array}{l}\text { A - } \\
\text { VE - }\end{array}$ & $\begin{array}{c}\mathrm{A}- \\
\mathrm{VE}-\end{array}$ & $\begin{array}{c}A- \\
V E-\end{array}$ & $\begin{array}{c}\text { A - } \\
\text { VE - }\end{array}$ & \begin{tabular}{|c|}
$\mathrm{A}-$ \\
$\mathrm{VE}-$
\end{tabular} & $\begin{array}{c}\text { A - } \\
\text { VE - }\end{array}$ & $\begin{array}{l}\mathrm{A}- \\
\mathrm{VE}-\end{array}$ & \begin{tabular}{|c|}
$\mathrm{A}-$ \\
$\mathrm{VE}-$
\end{tabular} & $\begin{array}{c}\text { A - } \\
\text { VE - }\end{array}$ & \begin{tabular}{|c|}
$A-$ \\
$V E-$
\end{tabular} & $\begin{array}{l}\text { A - } \\
\text { VE - }\end{array}$ \\
\hline 0 & 01 & 0 & 01 & 0 & 0 & 02 & 0 & 02 & 0 & 0 & 0 \\
\hline $\begin{array}{l}\text { B- } \\
V E-\end{array}$ & $\begin{array}{c}\mathrm{B}- \\
\mathrm{VE}-\end{array}$ & $\begin{array}{c}\mathrm{B}- \\
\mathrm{VE}-\end{array}$ & $\begin{array}{c}\mathrm{B}- \\
\mathrm{VE}-\end{array}$ & $\begin{array}{c}\mathrm{B}- \\
\mathrm{VE}-\end{array}$ & \begin{tabular}{|c|}
$\mathrm{B}-$ \\
$\mathrm{VE}-$
\end{tabular} & $\begin{array}{c}\mathrm{B}- \\
\mathrm{VE}-\end{array}$ & \begin{tabular}{|c|}
$\mathrm{B}-$ \\
$\mathrm{VE}-$
\end{tabular} & $\begin{array}{c}\mathrm{B}- \\
\mathrm{VE}-\end{array}$ & $\begin{array}{c}\mathrm{B}- \\
\mathrm{VE}-\end{array}$ & \begin{tabular}{|c|}
$\mathrm{B}-$ \\
$\mathrm{VE}-$
\end{tabular} & $\begin{array}{l}\mathrm{B}- \\
\mathrm{VE}-\end{array}$ \\
\hline 01 & 0 & 01 & 01 & 0 & 0 & 0 & 0 & 0 & 0 & 02 & 0 \\
\hline $\begin{array}{l}\mathrm{O}- \\
\mathrm{VE}-\end{array}$ & $0-$ & $\begin{array}{c}\mathrm{O}- \\
\mathrm{VE}-\end{array}$ & $\begin{array}{l}\mathrm{O}- \\
\mathrm{VE}-\end{array}$ & $\begin{array}{c}\text { O - } \\
\mathrm{VE}-\end{array}$ & $\begin{array}{c}\text { O- } \\
\text { VE - }\end{array}$ & $\begin{array}{c}\text { O - } \\
\text { VE - }\end{array}$ & $\begin{array}{c}\text { O- } \\
\mathrm{VE}-\end{array}$ & $\begin{array}{c}\text { O - } \\
\text { VE - }\end{array}$ & $0-$ & 0 - & $\begin{array}{c}0- \\
V E-\end{array}$ \\
\hline 02 & 0 & 0 & 01 & 0 & 0 & 0 & 01 & 0 & 02 & 02 & 0 \\
\hline \multicolumn{12}{|c|}{$\begin{array}{c}\text { Blood Group distribution in a Peripheral Blood Bank from } \\
\text { April } 2017 \text { to March } 2018 \text { (1 Year) }\end{array}$} \\
\hline
\end{tabular}

\begin{tabular}{|c|c|}
\hline Total Blood Bags & Screening Positive $(9)$ \\
\hline \multirow{3}{*}{1027} & HBsAg - 07 \\
\cline { 2 - 2 } & HIV - 04 \\
\cline { 2 - 2 } & HCV - 00 \\
\hline \multicolumn{2}{|c|}{ Table 2 } \\
\hline
\end{tabular}

(The total blood bags of 1027 is for the period of one year from April 2017 to March 2018).

Out of all 1027 blood bags collected, about 65\% were collected at the institutional inside blood bank and 35\% were collected outside in camps. Most of the donors were students.

\begin{tabular}{|c|c|c|}
\hline \multicolumn{3}{|c|}{ Blood Bag Distribution } \\
\hline Site & Nos. & Percentage \\
\hline Institutional Blood Bank & 651 & $65 \%$ \\
\hline Camps & 376 & $35 \%$ \\
\hline \multicolumn{2}{|c|}{ Table 3 } \\
\hline
\end{tabular}


The blood group frequency is analysed as follows

\begin{tabular}{|c|c|c|}
\hline Blood Group & Frequency(10),(11) & Percentage \\
\hline $\mathrm{A}+\mathrm{VE}$ & 171 & 27.45 \\
\hline $\mathrm{B}+\mathrm{VE}$ & 282 & 42.06 \\
\hline $\mathrm{O}+\mathrm{VE}$ & 432 & 4.47 \\
\hline $\mathrm{AB}+\mathrm{VE}$ & 46 & 0.58 \\
\hline $\mathrm{A}-\mathrm{VE}$ & 6 & 0.09 \\
\hline $\mathrm{B}-\mathrm{VE}$ & 1 & 0.19 \\
\hline $\mathrm{O}-\mathrm{VE}$ & 2 & \\
\hline
\end{tabular}

The comparison between Indian and peripheral blood bank frequency is as follows

\begin{tabular}{|c|c|c|}
\hline Blood Group & Indian Frequency & PBB-Frequency(12),(13) \\
\hline A & $27 \%$ & 16.65 \\
\hline B & $31 \%$ & 27.45 \\
\hline AB & $8 \%$ & 4.47 \\
\hline O & $34 \%$ & 42.06 \\
\hline \multicolumn{2}{|c|}{ Table 5 } \\
\hline
\end{tabular}

PBB- Peripheral Blood Bank.

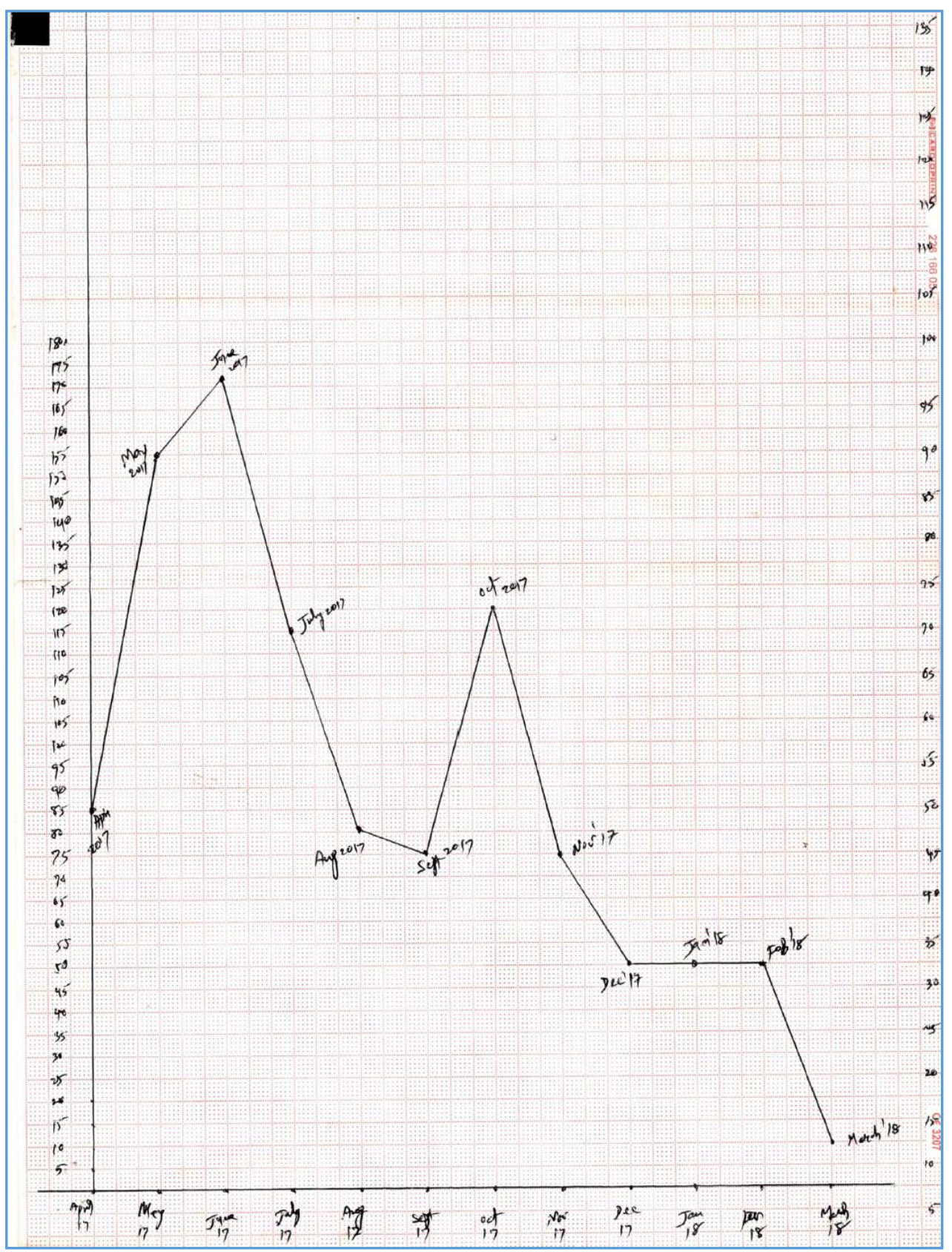




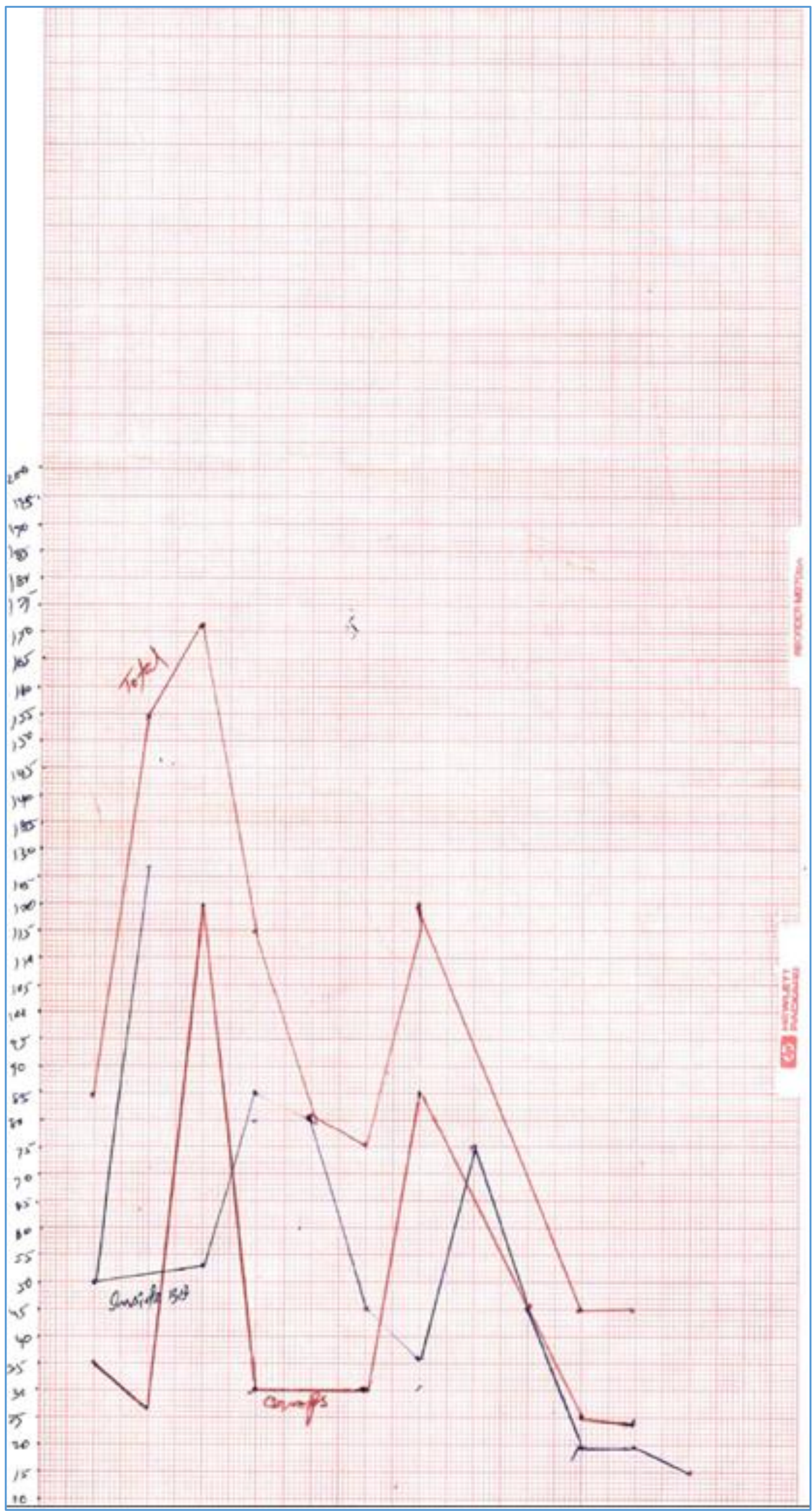




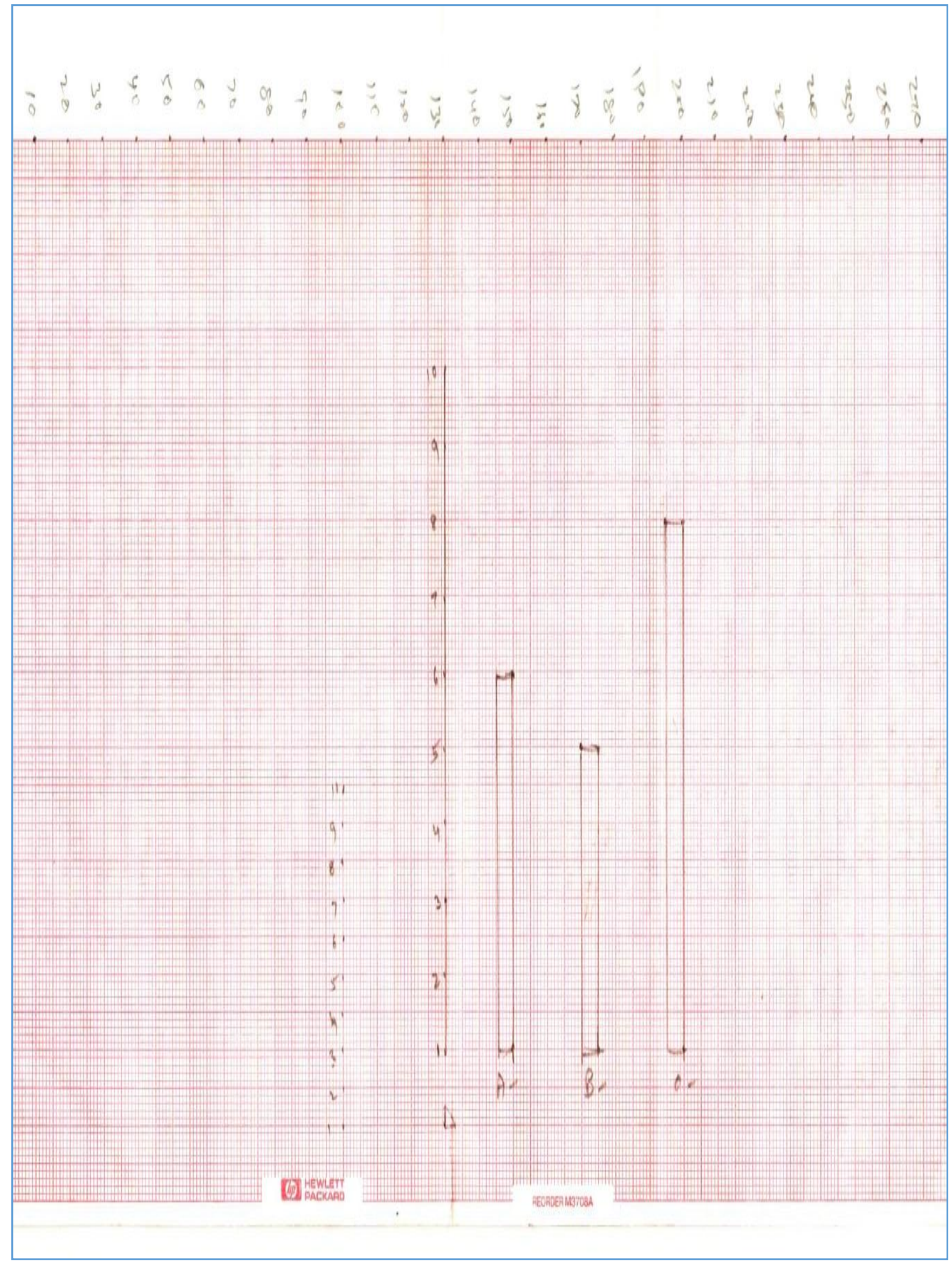




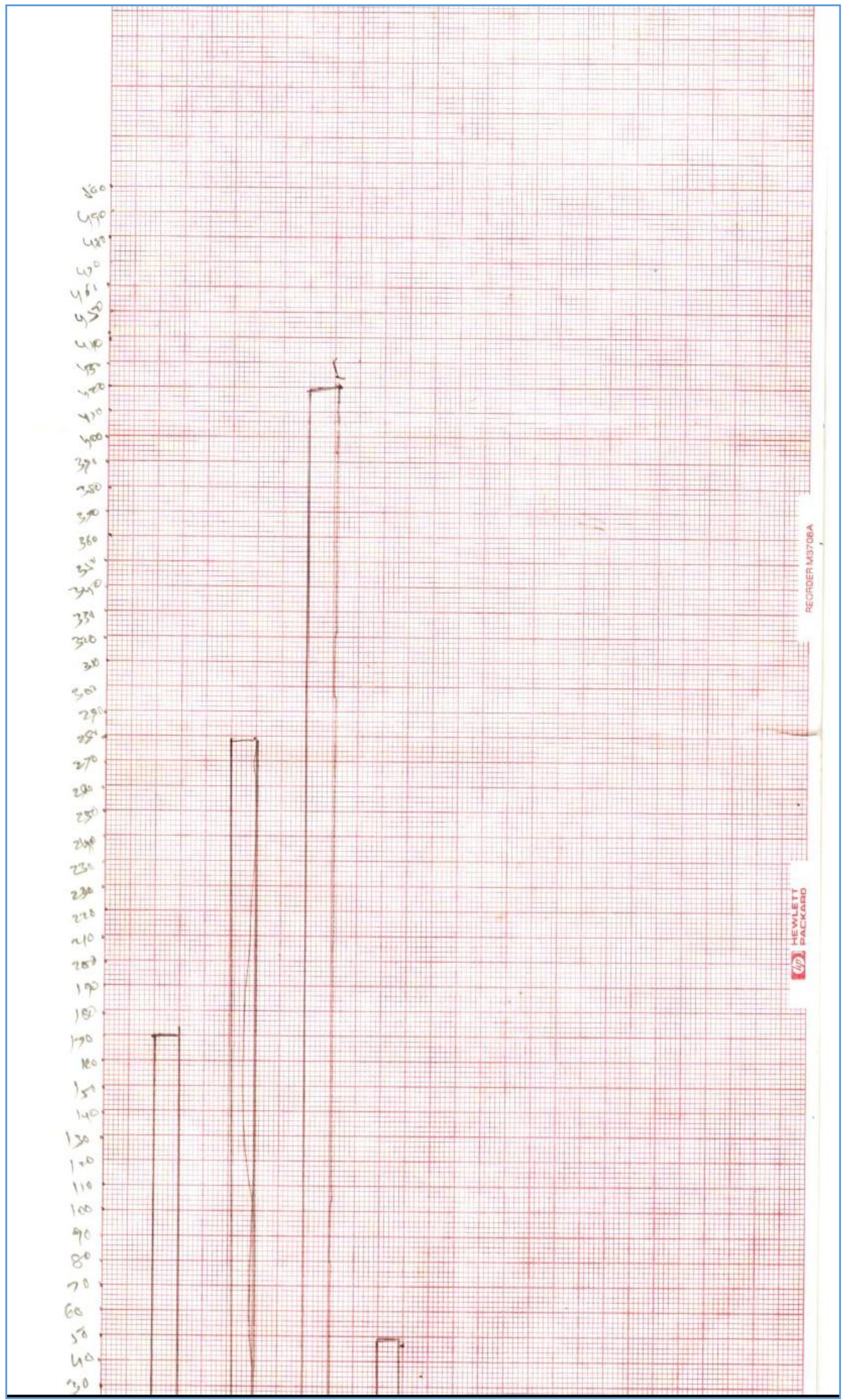




\section{DISCUSSION}

The blood donor behaviour means the particular group of donors can donate blood at particular period/ season of the year. For example, most of the student groups cannot donate blood during vacations like festivals as Dussehra, Pongal, Christmas and during hot summer. And students constitute important donor group and it needs less motivation for them. Most of them can readily agree to donate blood if camps are conducted outside at their schools/ colleges. The other group of non-student youth can also donate blood with some amount of motivation or coincidental occasions relating to personality cult like the birthday celebration of a political leader or the cine hero etc. Most of the donors who donate blood coming directly to the institutional blood bank are those who celebrate their own birthday. The rest of the groups of Indian society like the agricultural workers, factory workers and other urban work force often would not turn-up on their own without proper motivation or dire need.

\section{CONCLUSION}

Most of the donors issuing blood in camps are from student community and from petty political followers, but students issue blood at any time during their college or when they are at work and so they would not follow the seasons. The graph clearly shows gaps from Aug to Oct when the students are engaged in exam preparations, then during Dussehra holidays, from Dec to Jan due to semester exams and Christmas, New Year and Pongal holidays. Peak period for blood donation is mid Apr to mid Jun and mid Sept to mid Nov as they are relatively free. Though blood donation in camps and inside the institutions follow similar pattern of turnover, relatively wide gaps are noticed in camps particularly during the period July to September. In both the cases, ' $O$ ' group issue is more in number, but there is marginal variability between the issue of ' $A$ ' and ' $B$ ' groups. As per Table 5, blood donation at the institutional blood banks constitute about $65 \%$ of total issues and camps constitute about $35 \%$ of the total issues. This clearly indicates the donor confidence on the institution due to several safety factors like the facility need not be moved from the bank position and the availability of man power all the 24 hours and the motivation by blood bank counsellors.

Regarding the blood group distribution pattern, PBB (Peripheral Blood Bank) frequency of blood groups issue almost follows the average Indian frequency. As per Table 1 ' $O$ ' group constitute $34 \%$, whereas in PBB it is $42 \%(8 \%$ difference) and next in frequency is ' $\mathrm{B}$ ' group which has $31 \%$ and $27 \%$ (4\% difference) and later ' $A$ ' group which has $27 \%$ and $16 \%(11 \%)$ difference. In this study, no religious or racial groups are noticed in blood donation. It is average routine Indian pattern of society involved in blood donation.

List of donors of certain rare groups like Bombay blood group, subgroups and negative groups has to be maintained for easy access in case of dire emergencies. These days genetic study of blood groups is gaining scientific ground as the antigenic and allele variability is enormous due to the diversity of race, class, colour etc. Certain factors like temperate climate, ionising radiation, chemical pollution may influence the genetic material and cause mutations resulting in change in antigenic composition of the blood groups, thereby causing unforeseen incompatibility. Hence, blood group testing, cross-matching technology and methodology is not limited to the familiar card test, ELISA test etc., but has extended scope to the advanced genetic research. Only then blood transfusion can be safe and can win public confidence.

Apart from their importance in blood transfusion practice, the $\mathrm{ABO}$ and $\mathrm{Rh}$ blood groups are useful in clinical studies, population studies, genetic studies, researching population migration patterns, as well as resolving certain medico-legal issues, particularly of disputed paternity cases.

All human populations share the same blood group systems; although, they differ in the frequencies of specific types. The incidence of $\mathrm{ABO}$ and $\mathrm{Rh}$ group varies markedly in different races, ethnic groups and socio-economic groups in different parts of the world.

Knowledge of availability of different blood groups at various levels is the need of the hour for more efficient delivery of blood bank services.

\section{REFERENCES}

[1] Rao P, Annapurna K. HIV status of blood donors and patients admitted in KEM hospital Pune. Indian J Hemat Blood Transf 1994;12:174-6.

[2] Table of blood group systems. International Society of Blood Transfusion (ISBT). Oct 2008. URL:http://ibgrl.blood.co.uk/isbt.

[3] Widmann FK. Technical Manual American Associations of Blood Banks. USA: Anglington 1985: p. 325-44.

[4] Annual report to the people on Health, Government of India, Ministry of Health and Family Welfare, September, 2010. http://mohfw.nic.in/WriteReadData/1892s/9457038 092AnnualReporthealth.pdf)

[5] Van den Hurk K, Zalpuri S, Prinsze FJ, et al. Associations of health status with subsequent blood donor behaviour - An alternative perspective on the healthy donor effect from donor insight. PLoS One 2017;12(10):e0186662.

https://doi.org/10.1371/journal.pone.0186662 October 19, 2017.

[6] Wadhwa MK, Patel SM, Kothari DC, et al. Distribution of $\mathrm{ABO}$ and Rhesus-D groups in Gujarat, India: a hospital based study. Indian J Ped Oncol 1998;19(4):137-41.

[7] Periyavan S, Sangeetha SK, Marimuthu P, et al. Distribution of $\mathrm{ABO}$ and Rhesus-D, groups in and around Bangalore. Asian J Transfus Sci 2010;4(1):41.

[8] Mwangi J. Blood group distribution in an urban population of patient targeted blood donors. East Afr Med J 1999;76(11):615-8.

[9] Screening Donated Bloods for Transfusion Transmissible-Infections, WHO, 2009. (http://www.who.int/bloodsafety/ScreeningTTI.pdf).

[10] Rahman M, Lodhi Y. Frequency of ABO and Rhesus blood groups in blood donors in Punjab. Pak J Med Sci 2004;20:315-8.

[11] Giri PA, Yadav S, Parhar GS, et al. Frequency of ABO and Rhesus blood groups: a study from a rural tertiary care teaching hospital in India. Int J Bio \& Med Res 2011;2(4):988-90. 


\section{Jemds.com}

[12] Chandra T, Gupta A. Frequency of ABO and Rhesus blood groups in blood donors. Asian Journal of Transfusion Science 2012;6(1):50-3.
Original Research Article

[13] Mallikarjuna S. Prevalence of ABO and Rhesus blood group among blood donors. Indian J Pub Health Research and Development 2012;3(2):106-9. 